Received: 19 February 2019

Revision received: 15 March 2019

Copyright $\odot 2019$ ESTP

Accepted: 27 March 2019

www.estp.com.tr

DOI 10.12738/estp.2019.2.005 • April 2019 • 19(2)• 74-91

Article

\title{
Epidemiology of Cyberbullying across Europe: Differences between Countries and Genders
}

\author{
Anna Sorrentino \\ Università degli Studi della Campania \\ 'Luigi Vanvitelli', Italy \\ David P. Farrington \\ Institute of Criminology, Cambridge \\ University, $U K$
}

\author{
Anna Costanza Baldry* \\ Università degli Studi della Campania \\ 'Luigi Vanvitelli', Italy \\ Institute of Criminology, Cambridge \\ University, $U K$ \\ Catherine Blaya \\ UER Pedagogie Specialisee, HEP du \\ Canton de Vaud, Switzerland \\ URMIS, Universite Cote d'Azur, France
}

\begin{abstract}
Epidemiological studies on the prevalence of cyberbullying and cybervictimization in different countries, using the same procedure and the same measures, are of relevance in understanding differences in results that are not due to methodological factors. The current study was conducted in 8 European countries (Bulgaria, Cyprus, France, Greece, Hungary, Italy, Poland, and Spain), involving a total of 4,847 students, using an online anonymous questionnaire (the Tabby online questionnaire). The results were analyzed by comparing differences between countries and between genders. Cyberbullying and cybervictimization were most prevalent in Bulgaria and Hungary and least prevalent in Spain. Boys committed more cyberbullying than girls in all countries, but there were no overall gender differences in cybervictimization. However, girls were more often cybervictims in four countries and boys were more often cybervictims in the other four countries. The results are discussed with regard to the importance of cross-national studies of cyberbullying and cybervictimization and the use of online data collection in order to reduce methodological bias.
\end{abstract}

\section{Keywords}

Cyberbullying $\bullet$ cybervictimization $\bullet$ cross-national comparison $\bullet$ gender differences $\bullet$ online questionnaire

\footnotetext{
* This project was part of a wider EU funded grant to Anna Baldry: 2011/DAP/AG/3259 AMG. We are very grateful to all researchers who participated in this project. Sadly, Anna Baldry passed away after submitting this article.

Correspondence to David P. Farrington, Emeritus Professor, Institute of Criminology, Cambridge University. Sidgwick Avenue, Cambridge CB3 9DA, UK. Email: dpf1@ cam.ac.uk

Citation: Sorrentino, A., Baldry, A. C., Farrington, D. P., \& Blaya, C. (2019). Epidemiology of Cyberbullying across Europe: Differences between Countries and Genders. Educational Sciences: Theory \& Practice, 19(2), 74-91. http://dx.doi.org/10.12738/estp.2019.2.005
} 


\section{Background}

Cyberbullying is a problem faced in many Western and Eastern countries, affecting children from their first grades up to their late teens (Aoyama, Utsumi, \& Hasegawa, 2012; Nocentini et al., 2010; Tippett $\&$ Kwak, 2012). Though studies about the prevalence and nature of cyberbullying in different countries have shown significant differences globally, ranging from 10-40\% for victimization and from 3-50\% for perpetration (Kowalski, Giumetti, Schroeder, \& Lattanner, 2014), it is not possible in most cases to make direct comparisons between countries unless the same procedures, same methods, and comparable samples are used. Furthermore, as underlined by Smith, Görzig, and Robinson (2018) large-scale surveys involving many countries are currently not very common.

The data collection procedures, for example, using paper and pencil self-report questionnaires or face-to-face interviews, might also affect the answers, as might the settings where data are collected. Using an online structured questionnaire to measure cyberbullying and to compare results in different countries is a reliable procedure, as the instruments and the method are uniform between different countries. In addition, when students fill in the online questionnaire in a dedicated information technology (IT) class, methodological errors are reduced to a minimum and comparisons are more reliable. Students also feel more at ease (Slee \& Mohyla, 2014; van den Berg \& Gommans, 2017) in replying and have an additional sense of privacy (Baldry, Blaya, \& Farrington, 2018; van den Berg \& Gommans, 2017). The use of computers as a tool to overcome methodological problems of cross-cultural comparative studies should be a viable procedure, especially when dealing with sensitive topics such as online bullying perpetration and victimization (Davis, Hoffman, Morse, \& Luehr, 1992; Slee \& Mohyla, 2014).

The data analyzed in this article were collected as baseline data for the Threat Assessment of Bullying Behaviours among Youngsters (Tabby) programme. This programme aimed to reduce cyberbullying (and cybervictimization) by increasing awareness about the risks related to an individual's own use of cyber communication and reducing the risk of falling into the most common "online traps" (see Baldry et al., 2018). It was developed initially in 2010 and implemented in 2011-2013 in Italy and a further four EU countries (Bulgaria, Greece, Cyprus, and Hungary) and was later used in an additional three EU countries (Spain, France, and Poland). The development and implementation of the programme were supported by the European Union Daphne Security and Justice Programme for the reduction of violence against women and children. The principal investigators in each country were: Anna Costanza Baldry (Italy, and overall), Catherine Blaya (France), Bassam Aouli (Poland), Antonio Maldonado (Spain), Katalin Parti (Hungary), Andreas Kapardis (Cyprus), Christina Athanasiades (Greece), and Svetla Encheva (Bulgaria).

\section{Definition of cyberbullying}

Different authors from different countries have provided several definitions of cyberbullying, with similar features. Tokunaga $(2010$, p. 278) provides an integrative definition which tries to capture all relevant aspects that could be applied to different countries: "Cyberbullying is any behavior performed through electronic or digital media by individuals or groups that repeatedly communicates hostile or aggressive messages intended to inflict harm or discomfort to others". This definition, as well as all the similar ones provided by other authors in different countries (Besley, 2009; Finkelhor, Mitchell, \& Wolak, 2000; Juvonen \& Gross, 2008; Li, 2008; Patchin \& Hinduja, 2006; Slonje \& Smith, 2008; Smith et al., 2008; Willard, 2007; Ybarra \& Mitchell, 2004), has similar features to the definition of traditional bullying (Olweus, 1993) with regard to the intention to harm and the imbalance of power.

However, there are different opinions among scholars with regard to what it is meant with the term 'repeated actions'. Some authors claim that it is enough to have one or two cyberbullying actions (Baldry, 
Farrington, \& Sorrentino, 2017; Gámez-Guadix, Orue, Smith, \& Calvete, 2013; Juvonen \& Gross, 2008; Kowalski \& Limber, 2007; Li, 2007; Vieno, Gini, \& Santinello, 2011; Ybarra \& Mitchell, 2004). A single cyber-threat (e.g., a video, a comment, a picture) can stay online or in a smartphone for quite some time, and can be viewed by numerous people, thereby prolonging the exposure to potential harm (Dooley, Pyzalski, \& Cross, 2009; Raskauskas \& Stoltz, 2007; Slonje, Smith, \& Frisén, 2013).

\section{International comparisons of cyberbullying}

Directly comparable studies on the prevalence and nature of cyberbullying and cybervictimization using the same instruments are summarized in Table 1. The EU Kids Online is the most extensive European cross-national study, involving 25,142 students from 25 European countries. The results showed that 1 in 5 children in Western and Eastern Europe reported being cybervictimized, with higher prevalence rates in Poland and lower rates in Belgium (Hasebrink, Livingstone, \& Haddon, 2008). From the same study, Lobe, Livingstone, Ólafsson, and Vodeb (2011) reported that $6 \%$ and $3 \%$ respectively were cybervictims and cyberbullies, with Romanian and Estonian children reporting the highest prevalence of cyberbullying. Concerning gender differences, Spanish, Finnish, and Lithuanian girls were more likely than boys to experience cybervictimization.

Li (2008) carried out the first study comparing Western (Canadian) and non-Western (Chinese) students involved in cyberbullying. The results showed that more Canadian than Chinese students reported that they had cyberbullied others, while no significant differences were found concerning cybervictimization. According to the authors, the results suggest that easier access to the Internet and communication technologies in Canada could explain the higher prevalence of cyberbullying. No gender differences were reported.

Mura, Topcu, Erdur-Baker, and Diamantini (2011) carried out a cross-cultural study comparing Italian and Turkish university students' experience of cyberbullying and cybervictimization. The country differences in cyberbullying and cybervictimization were explained by different students' frequencies of Information and Communication Technology (ICT) use, rather than by different cultural factors influencing the results. No direct gender comparisons were reported.

Ortega et al. (2012) compared cybervictimization rates between English, Italian, and Spanish students, with Italian and English students reporting higher rates of mobile phone cybervictimization compared to Spanish students, and English students reporting higher Internet cybervictimization compared to Italian and Spanish students. Ang, Huan, and Florell (2013) compared cyberbullying in the US and Singapore, reporting no significant differences between countries; $17.9 \%$ of US and $16.4 \%$ of Singapore students were involved in cyberbullying at least once or twice in the current school year.

Barlett et al. (2014) carried out a cross-cultural study, comparing US and Japanese students, with a longitudinal design to assess cross-cultural change in cyberbullying. The results showed country differences concerning positive attitudes towards cyberbullying, interdependent self-construal and cyberbullying prevalence, with the US male participants scoring higher on cyberbullying. Del Rey et al. (2015) gathered data from students from six European countries (Spain, Germany, Italy, Poland, England, and Greece) to validate at a cross-national level the European Cyberbullying Intervention Project Questionnaire (ECIPQ; Brighi et al., 2012). The results showed that Greek, Italian, and Polish students reported a higher prevalence of both cyberbullying and cybervictimization. 
Table 1. Cross-national comparison studies adopting the same measurements

\begin{tabular}{|c|c|c|c|c|c|c|}
\hline \multirow{2}{*}{$\begin{array}{l}\text { Nations compared } \\
\text { Canada and China }\end{array}$} & \multirow{2}{*}{$\begin{array}{l}\text { Study } \\
\\
\mathrm{Li} \\
(2008)\end{array}$} & \multirow{2}{*}{$\begin{array}{l}\text { Total sample, } \\
\text { age, method, } \\
\text { time reference } \\
\text { period } \\
354 \\
7^{\text {th }} \text { grade } \\
\text { Self-report } \\
\text { questionnaire } \\
\text { Not reported }\end{array}$} & \multirow{2}{*}{$\begin{array}{l}\text { Instrument } \\
\text { Survey } 3 \text { items } \\
\text { for CB and } 4 \\
\text { items for CV } \\
\text { from less than } 4 \\
\text { times to over } 10 \\
\text { times }\end{array}$} & \multirow{2}{*}{$\begin{array}{l}\text { Criteria } \\
\text { CB/CV } \\
\text { At least } \\
\text { one - } \\
\text { three } \\
\text { times }\end{array}$} & \multicolumn{2}{|c|}{ Main results } \\
\hline & & & & & $\begin{array}{l}25.0 \% \text { of Canadian } \\
\text { and } 33.0 \% \text { of } \\
\text { Chinese students } \\
\text { reported } \\
\text { cybervictimization. }\end{array}$ & $\begin{array}{l}15.0 \% \text { of Canadian and } \\
7.0 \% \text { of Chinese } \\
\text { students reported } \\
\text { cyberbullying. }\end{array}$ \\
\hline Italy and Turkey & $\begin{array}{l}\text { Mura } \\
\text { et al. } \\
(2011)\end{array}$ & $\begin{array}{l}337 \\
\text { IT }=18-33 \text { years } \\
\text { TR=18-36 years } \\
\text { Self-report } \\
\text { questionnaire } \\
\text { Past } 6 \text { months }\end{array}$ & $\begin{array}{l}\text { Items were } \\
\text { based on the } \\
\text { Revised } \\
\text { CyberBullying } \\
\text { Inventory } \\
\text { (RCBI; Topcu } \\
\text { \& Erdur - } \\
\text { Baker, 2010) } 8 \\
\text { items for CB } \\
\text { and } 8 \text { items for } \\
\text { CV on 3-point } \\
\text { scale (from } \\
\text { never to } 3 \text { times } \\
\text { or more) }\end{array}$ & $\begin{array}{l}\text { At least } \\
\text { once }\end{array}$ & $\begin{array}{l}\text { The most common } \\
\text { types of } \\
\text { cybervictimization } \\
\text { were gossip for } \\
\text { Italian students } \\
(30.5 \%) \text { and prank } \\
\text { calls (42.9\%) for } \\
\text { Turkish students. }\end{array}$ & $\begin{array}{l}\text { Regarding } \\
\text { cyberbullying, Italian } \\
\text { students reported higher } \\
\text { rates of gossiping } \\
(27.8 \%) \text {, publication of } \\
\text { private messages } \\
(19.0 \%) \text {, and } \\
\text { embarrassing photos } \\
(7.0 \%) \text {. Turkish } \\
\text { students reported higher } \\
\text { levels of prank calls } \\
(21.7 \%) \text {, and mean, } \\
\text { threatening email/ text } \\
(13.7 \%) .\end{array}$ \\
\hline $\begin{array}{l}\text { Austria, Belgium, } \\
\text { Bulgaria, Cyprus, } \\
\text { Czech Republic, } \\
\text { Denmark, Estonia, } \\
\text { France, Finland, } \\
\text { Germany, Greece, } \\
\text { Hungary, Ireland, } \\
\text { Italy, Lithuania, the } \\
\text { Netherland, } \\
\text { Norway, Poland, } \\
\text { Portugal, Romania, } \\
\text { Spain, } \\
\text { Slovenia, Sweden, } \\
\text { Turkey, and United } \\
\text { Kingdom }\end{array}$ & $\begin{array}{l}\text { Lobe } \\
\text { et al. } \\
(2011)\end{array}$ & $\begin{array}{l}25,142 \\
9-16 \text { years } \\
\text { Face to face } \\
\text { interview } \\
\text { In the last } 12 \\
\text { months }\end{array}$ & $\begin{array}{l}\text { EU Kids Online } \\
\text { Survey } \\
2 \text { items for CB } \\
\text { and CV with } 3 \\
\text { items response } \\
\text { options: no or } \\
\text { yes }\end{array}$ & $\begin{array}{l}\text { Not } \\
\text { reported }\end{array}$ & $\begin{array}{l}\text { In Romania } \\
(14.0 \%) \text { and } \\
\text { Estonia }(13.0 \%) \\
\text { cyberbullying is } \\
\text { more than twice } \\
\text { the average. } \\
\text { Cyberbullying } \\
\text { rates are lower in } \\
\text { some Southern } \\
\text { European countries } \\
\text { (Portugal, Italy, } \\
\text { Turkey, and } \\
\text { Greece) and the } \\
\text { Netherlands. }\end{array}$ & $\begin{array}{l}\text { Regarding the total } \\
\text { sample, } 6 \% \text { of } \\
\text { participants were } \\
\text { cybervictimized while } \\
3 \% \text { were cyberbullies. }\end{array}$ \\
\hline $\begin{array}{l}\text { England, Italy, and } \\
\text { Spain }\end{array}$ & $\begin{array}{l}\text { Ortega } \\
\text { et al. } \\
(2012)\end{array}$ & $\begin{array}{l}5,862 \\
8-10-12 \text { grades } \\
\text { Self-report } \\
\text { questionnaire } \\
\text { Past } 2 \text { months }\end{array}$ & $\begin{array}{l}\text { DAPHNE } \\
\text { Questionnaire } \\
\text { (Genta et al. } \\
\text { 2012) } \\
12 \text { items for } \\
\text { mobile phones } \\
\text { CV and } 12 \\
\text { items for } \\
\text { Internet CV on } \\
\text { a 5-point Likert } \\
\text { scale (from } \\
\text { never to several } \\
\text { times a week) }\end{array}$ & $\begin{array}{l}\text { At least } \\
\text { once or } \\
\text { twice }\end{array}$ & $\begin{array}{l}\text { Mobile phone } \\
\text { frequent } \\
\text { victimization: } 2.0 \% \\
\text { (EN) } 2.2 \% \text { (IT) } 0.5 \\
\% \text { (ES). }\end{array}$ & $\begin{array}{l}\text { Internet frequent } \\
\text { victimization: } \\
2.6 \%(\mathrm{EN}), 1.9 \% \text { (IT), } \\
1.3 \%(\mathrm{ES})\end{array}$ \\
\hline USA and Singapore & $\begin{array}{l}\text { Ang et } \\
\text { al. } \\
(2013)\end{array}$ & $\begin{array}{l}757 \\
11-17 \text { years } \\
\text { Self-report } \\
\text { questionnaire } \\
\text { The current } \\
\text { school term }\end{array}$ & $\begin{array}{l}\text { Cyberbullying } \\
\text { Questionnaire } \\
\text { (Ang \& Goh, } \\
2010 \text { ) } 9 \text { items } \\
\text { for CB on a 5- } \\
\text { point Likert } \\
\text { scale (from } \\
\text { never to a few }\end{array}$ & $\begin{array}{l}\text { At least } \\
\text { once or } \\
\text { twice }\end{array}$ & $\begin{array}{l}17.9 \% \text { of United } \\
\text { States and } 16.4 \% \\
\text { of Singapore } \\
\text { students were } \\
\text { involved in } \\
\text { cyberbullying. }\end{array}$ & \\
\hline
\end{tabular}


times every

week)

\begin{tabular}{|c|c|c|c|c|c|c|}
\hline Japan and USA & $\begin{array}{l}\text { Barlett } \\
\text { et al. } \\
(2014)\end{array}$ & $\begin{array}{l}980 \\
M_{\text {age }}=20.51 \\
\text { Self-report } \\
\text { questionnaire } \\
\text { The past year }\end{array}$ & $\begin{array}{l}\text { Cyber behavior } \\
\text { questionnaire } \\
\text { (Ybarra et al., } \\
2007 \text { ) } \\
3 \text { items for CB }\end{array}$ & $\begin{array}{l}\text { At least } \\
\text { once or } \\
\text { twice }\end{array}$ & $\begin{array}{l}\text { US students } \\
\text { reported higher } \\
\text { involvement in } \\
\text { cyberbullying than } \\
\text { Japanese ones. }\end{array}$ & $\begin{array}{l}\text { Both US and Japanese } \\
\text { male students scored } \\
\text { higher on cyberbullying } \\
\text { involvement than } \\
\text { females. }\end{array}$ \\
\hline $\begin{array}{l}\text { Poland, Spain, Italy, } \\
\text { England, Germany, } \\
\text { and Greece }\end{array}$ & $\begin{array}{l}\text { Del } \\
\text { Rey et } \\
\text { al. } \\
(2015)\end{array}$ & $\begin{array}{l}5,679 \\
11-23 \text { years } \\
\text { Self-report } \\
\text { questionnaire } \\
\text { Not reported }\end{array}$ & $\begin{array}{l}\text { The European } \\
\text { Cyberbullying } \\
\text { Intervention } \\
\text { Project } \\
\text { Questionnaire } \\
\text { (Brighi et al., } \\
2012 \text { ) } \\
11 \text { items for CB } \\
\text { and } 11 \text { items } \\
\text { for CV on a 5- } \\
\text { point Likert } \\
\text { scale (from } \\
\text { never to several } \\
\text { times a week) }\end{array}$ & $\begin{array}{l}\text { At least } \\
\text { once a } \\
\text { month }\end{array}$ & $\begin{array}{l}\text { Cybervictimization } \\
\text { rates: } 10.14 \% \\
(\mathrm{GR}), 8.04 \%(\mathrm{IT}), \\
6.37 \%(\mathrm{EN}), \\
6.11 \%(\mathrm{PL}), 4.65 \% \\
(\mathrm{ES}) \text { and } 4.13 \\
(\mathrm{DE}) \text {. }\end{array}$ & $\begin{array}{l}\text { Cyberbullying rates: } \\
7.82 \%(\mathrm{GR}), 6.85 \% \\
(\mathrm{DE}), 6.77 \%(\mathrm{PL}) \text {, } \\
5.52 \%(\mathrm{IT}), 5.12 \%(\mathrm{ES}) \\
\text { and } 0.94 \%(\mathrm{EN}) .\end{array}$ \\
\hline Iran and Finland & $\begin{array}{l}\text { Jagho } \\
\text { ory et } \\
\text { al. } \\
(2015)\end{array}$ & $\begin{array}{l}1,250 \\
M_{\text {age }}=12.7 \\
(S D=2.1) \\
\text { Self-report } \\
\text { questionnaire } \\
\text { Not reported }\end{array}$ & $\begin{array}{l}\text { The Mini- } \\
\text { Direct \& } \\
\text { Indirect } \\
\text { Aggression } \\
\text { Scales } \\
\text { (Österman, } \\
\text { 2008) } \\
6 \text { items for CB } \\
\text { and } 6 \text { items for } \\
\text { CV on a 5-point } \\
\text { Likert scale } \\
\text { (from never to } \\
\text { several times a } \\
\text { week) }\end{array}$ & $\begin{array}{l}\text { Not } \\
\text { reported }\end{array}$ & $\begin{array}{l}\text { All types of } \\
\text { cybervictimization } \\
\text { behaviors were } \\
\text { significantly higher } \\
\text { among Iranian } \\
\text { students. The same } \\
\text { applies to } \\
\text { cyberbullying, } \\
\text { Iranian adolescents } \\
\text { performed more } \\
\text { cyberbullying, of } \\
\text { all kinds, than } \\
\text { Finnish } \\
\text { adolescents. }\end{array}$ & $\begin{array}{l}\text { Regarding } \\
\text { cybervictimization in } \\
\text { both countries, girls } \\
\text { were more exposed to } \\
\text { nasty telephone } \\
\text { communications and } \\
\text { nasty e-mails, while } \\
\text { boys were more } \\
\text { exposed to being filmed } \\
\text { while someone else was } \\
\text { evil against them. }\end{array}$ \\
\hline $\begin{array}{l}\text { Spain, Poland, the } \\
\text { Netherlands, } \\
\text { Romania, Iceland, } \\
\text { and Greece }\end{array}$ & $\begin{array}{l}\text { Tsitsik } \\
\text { a et al. } \\
(2015)\end{array}$ & $\begin{array}{l}10,930 \\
14-17 \text { years } \\
\text { Self-report } \\
\text { questionnaire } \\
\text { Past } 12 \text { months }\end{array}$ & $\begin{array}{l}\text { Questionnaire } \\
\text { developed by } \\
\text { the EU NET } \\
\text { ADB } \\
\text { consortium } \\
\text { (Tsitsika et al., } \\
2013 \text { ) } \\
1 \text { item for CV } \\
\text { with } 3 \text { response } \\
\text { options: no, yes } \\
\text { and do not } \\
\text { know/prefer not } \\
\text { to say. }\end{array}$ & $\begin{array}{l}\text { Not } \\
\text { reported }\end{array}$ & $\begin{array}{l}21.4 \% \text { of the } \\
\text { students reported } \\
\text { cybervictimization } \\
\text { in the past } 12 \\
\text { months. }\end{array}$ & $\begin{array}{l}\text { Cybervictimization } \\
\text { prevalence is highest in } \\
\text { Romania }(37.3 \%) \text { and } \\
\text { Greece }(26.8 \%) \text { and } \\
\text { lowest in Iceland } \\
(13.5 \%) \text { and Spain } \\
(13.3 \%) \text {. }\end{array}$ \\
\hline $\begin{array}{l}\text { China, India, and } \\
\text { Japan }\end{array}$ & $\begin{array}{l}\text { Wrigh } \\
\text { t et al. } \\
(2015)\end{array}$ & $\begin{array}{l}1,637 \\
11-15 \text { years } \\
\text { Self-report } \\
\text { questionnaire } \\
\text { During the school } \\
\text { years }\end{array}$ & $\begin{array}{l}\text { Cyber } \\
\text { Aggression } \\
\text { Involvement } \\
9 \text { items for CB, } \\
9 \text { items for CV } \\
\text { on a 5-point } \\
\text { Likert scale } \\
\text { (from never to } \\
\text { several times a } \\
\text { week) }\end{array}$ & $\begin{array}{l}\text { At least } \\
\text { once or } \\
\text { twice }\end{array}$ & $\begin{array}{l}\text { Indian adolescents } \\
\text { reported more } \\
\text { cyberbullying }(M= \\
1.86 ; S D=0.74) \\
\text { and cyber } \\
\text { victimization }(M= \\
1.79 ; S D=0.86) \\
\text { than adolescents } \\
\text { from China and } \\
\text { Japan. }\end{array}$ & \\
\hline
\end{tabular}




\begin{tabular}{|c|c|c|c|c|c|c|}
\hline $\begin{array}{l}\text { Germany, } \\
\text { Netherlands, USA, } \\
\text { and Thailand }\end{array}$ & $\begin{array}{l}\text { Wachs } \\
\text { et al. } \\
(2016)\end{array}$ & $\begin{array}{l}2,162 \\
11-19 \text { years } \\
\text { Self-report } \\
\text { questionnaire } \\
\text { Last } 12 \text { months }\end{array}$ & $\begin{array}{l}\text { Cybergrooming } \\
\text { instrument } \\
\text { (Wachs et al., } \\
\text { 2012) } \\
1 \text { item for } \\
\text { cybergrooming } \\
\text { ranging on a 5- } \\
\text { point Likert } \\
\text { scale (from } \\
\text { never to several } \\
\text { times a week) }\end{array}$ & $\begin{array}{l}\text { At least } \\
\text { once or } \\
\text { twice }\end{array}$ & $\begin{array}{l}\text { Fewer Western } \\
\text { participants } \\
\text { reported having } \\
\text { contact with a } \\
\text { cybergroomer } \\
\text { compared with } \\
\text { Southeast Asian } \\
\text { participants }(9.9 \% \\
\text { vs. } 36.5 \%) \text {. }\end{array}$ & $\begin{array}{l}\text { Regarding gender and } \\
\text { country-differences, } \\
\text { results showed that } \\
\text { Western girls were } \\
\text { more at risk of } \\
\text { becoming victims of } \\
\text { cybergrooming } \\
\text { compared with Western } \\
\text { boys ( } 14.0 \% \text { vs. } 6.1 \% \text { ), } \\
\text { while this gender } \\
\text { difference was not } \\
\text { found for Thai } \\
\text { adolescents (boys } \\
40.4 \% \text { vs girls } 34.7 \% \text { ). }\end{array}$ \\
\hline Korea and Australia & $\begin{array}{l}\text { Lee et } \\
\text { al. } \\
(2017)\end{array}$ & $\begin{array}{l}921 \\
12-15 \text { years } \\
\text { Face-to-face } \\
\text { survey } \\
\text { Last } 12 \text { months }\end{array}$ & $\begin{array}{l}\text { Interview } \\
4 \text { examples of } \\
\text { online bullying } \\
\text { behaviors } \\
1 \text { item for CB, } \\
1 \text { item for CV, } \\
\text { and/or CV } \\
\text { severity ranging } \\
\text { on a } 6 \text {-point } \\
\text { scale (form } \\
\text { never to very } \\
\text { often) }\end{array}$ & $\begin{array}{l}\text { At least } \\
\text { once }\end{array}$ & $\begin{array}{l}\text { Australian } \\
\text { participants were } \\
\text { more involved in } \\
\text { both cyberbullying } \\
\text { and } \\
\text { cybervictimization. }\end{array}$ & $\begin{array}{l}40.6 \% \text { of Australian } \\
\text { adolescents and } 30.2 \% \\
\text { of Korean adolescents } \\
\text { were cyberbullies while } \\
60.1 \% \text { of Australian } \\
\text { participants and } 30.2 \% \\
\text { of Korean students } \\
\text { reported they have been } \\
\text { cybervictimized. }\end{array}$ \\
\hline $\begin{array}{l}\text { Germany, Greece, } \\
\text { Iceland the } \\
\text { Netherlands, } \\
\text { Poland, Romania, } \\
\text { and Spain }\end{array}$ & $\begin{array}{l}\text { Athan } \\
\text { asiou } \\
\text { et al. } \\
\text { (2018) }\end{array}$ & $\begin{array}{l}12,372 \\
9 \text { to } 10 \text { grades } \\
\text { Self-report } \\
\text { questionnaire } \\
\text { Last } 12 \text { months }\end{array}$ & $\begin{array}{l}\text { Self-report } \\
\text { questionnaire } \\
1 \text { item for CV } \\
\text { (with three } \\
\text { possible } \\
\text { answers: no, } \\
\text { yes } \\
\text { and do not } \\
\text { know/prefer not } \\
\text { to say) }\end{array}$ & $\begin{array}{l}\text { At least } \\
\text { once }\end{array}$ & $\begin{array}{l}21.9 \% \text { of the total } \\
\text { sample } \\
\text { experienced } \\
\text { cybervictimization. }\end{array}$ & $\begin{array}{l}\text { The highest rate of } \\
\text { cybervictimization was } \\
\text { found in Romania } \\
(37.3 \%) \text {, followed by } \\
\text { Greece }(26.8 \%) \text {, } \\
\text { Germany }(24.3 \%) \text {, } \\
\text { Poland }(21.5 \%) \text {, the } \\
\text { Netherlands }(15.5 \%) \text {, } \\
\text { and Iceland }(13.5 \%) \text {. } \\
\text { Spanish participants } \\
\text { reported the lowest } \\
\text { rates of involvement in } \\
\text { cybervictimization } \\
(13.3 \%) \text {. }\end{array}$ \\
\hline $\begin{array}{l}\text { Colombia, Uruguay, } \\
\text { and Spain }\end{array}$ & $\begin{array}{l}\text { Yudes } \\
- \\
\text { Góme } \\
\text { z et al. } \\
\text { (2018) }\end{array}$ & $\begin{array}{l}2,653 \\
10-18 \text { years } \\
\text { Self-report } \\
\text { questionnaire } \\
\text { Not reported }\end{array}$ & $\begin{array}{l}\text { Cuestionario de } \\
\text { Ciberacoso } \\
\text { (CBQ; Calvete } \\
\text { et al., 2010; } \\
\text { Estévez et al., } \\
\text { 2010; Gámez- } \\
\text { Guadix et al., } \\
\text { 2014) } 17 \text { items } \\
\text { for CB and } 11 \\
\text { items for CV } \\
\text { ranging on a 4- } \\
\text { point Likert } \\
\text { scale (from } \\
\text { never to } 5 \text { or } \\
\text { more times) }\end{array}$ & $\begin{array}{l}\text { At least } \\
\text { three or } \\
\text { more } \\
\text { times }\end{array}$ & $\begin{array}{l}\text { Colombian } \\
\text { adolescents were } \\
\text { less involved than } \\
\text { Spanish and } \\
\text { Uruguayan } \\
\text { adolescents in both } \\
\text { cyberbullying and } \\
\text { cybervictimization. }\end{array}$ & $\begin{array}{l}\text { Regarding adolescents' } \\
\text { severe involvement in } \\
\text { both cyberbullying and } \\
\text { cybervictimization no } \\
\text { significant differences } \\
\text { across countries were } \\
\text { found. }\end{array}$ \\
\hline
\end{tabular}

Notes: $\mathrm{CB}=$ Cyberbullying; $\mathrm{CV}=$ Cybervictimization

$\mathrm{DE}=$ Germany $; \mathrm{EN}=$ England $; \mathrm{ES}=$ Spain $; \mathrm{GR}=$ Greece $; \mathrm{IT}=$ Italy $; \mathrm{PL}=$ Poland $; \mathrm{USA}=$ United States of America

$M=$ mean; $S D=$ standard deviation. 
Jaghoory, Björkqvist, and Österman (2015) surveyed 630 Iranian and 620 Finnish adolescents in order to investigate differences in involvement in cyberbullying and cybervictimization. Iranian students scored higher in both cyberbullying and cybervictimization. However, regarding gender differences, Finnish girls were more likely to cyberbully others, while no gender differences were found in the Iranian sample. The authors hypothesized that higher levels of cyberbullying and cybervictimization could be a result of higher levels of aggressiveness in Iranian students because of the psychological challenges to which they are exposed in their society. However, the study did not provide support for this hypothesis, since students' aggressiveness was not measured.

Tsitsika et al. (2015), in their cross-national study, involving students from Spain, Poland, the Netherlands, Romania, Iceland, and Greece found similar to Del Rey et al. (2015) and Lobe et al. (2011), that cybervictimization rates were highest in Romania (37.3\%) and Greece (26.8\%). In another comparative study, Wright et al. (2015) compared data on cyberbullying and cybervictimization gathered from 1,637 Indian, Chinese, and Japanese students. The results revealed that Indian students had the highest prevalence of cyberbullying compared to Chinese and Japanese adolescents. The same conclusion was drawn concerning students' experience of being cybervictimized, with Indian students reporting higher rates of cybervictimization. Blaya, Sandaram, Kirandeep, and Sandhu (2015) compared French and Indian students' experiences of cybervictimization, by surveying a total of 2,333 adolescents. The results showed some country differences, with Indian students more likely to be cybervictimized than French students, in agreement with the results of Wright et al. (2015).

In more recent cross-national studies, Lee and Shin (2017) found, by comparing Australian and Korean students aged 12-15 years, that Australian students were more involved in both cyberbullying and cybervictimization. Yudes-Gómez, Baridon-Chauvie, and González-Cabrera (2018) surveyed 2,653 Spanish, Colombian, and Uruguayan students about their cyberbullying and cybervictimization experiences. The results showed that Colombian adolescents reported the lowest rates of involvement in both cyberbullying and cybervictimization compared with Spanish and Uruguayan adolescents, while Uruguayan adolescents reported highest rates of severe cybervictimization. Athanasiou et al. (2018) compared data on cybervictimization gathered from 12,372 students in seven different EU countries. Similar to Tsitsika et al. (2015), Del Rey et al. (2015), and Lobe et al. (2011), cybervictimization rates were highest in Romania and Greece.

These studies show variations regarding prevalence rates and types of involvement in cyberbullying between countries. It is difficult to explain the differences, as they could be a function of individual characteristics as well as the cultural context. As pointed out by Tsitsika et al. (2015), the use of the Internet and Social Networking Sites (SNS) is strongly associated with a high risk of being involved in cyberbullying. Differences in results could be related to the way students go online (e.g., number of hours, online profile network, number of known online friends), in addition to cultural differences associated with the use of online communication and electronic devices. The differences should also be studied from a gender perspective, as cultural gender differences might also play a role. Boys traditionally have been reported as more involved in antisocial behaviors, including school bullying, while girls are more likely to be victims (Slonje, Smith, \& Frisén, 2013).

As stated by Lee and Shin (2017), additional cross-national research comparing the nature and prevalence of cyberbullying and cybervictimization in different countries is needed to provide a greater understanding of the experience of cyberbullying by adolescents (see also Bauman \& Bellmore, 2015; Li, 2008). 


\section{Objectives of this study}

In the present study, we aimed to provide data on the prevalence and nature of cyberbullying and cybervictimization among adolescents in eight European countries, and to capture national/cultural differences by comparing types of behaviors and addressing gender differences using a newly developed online data collection questionnaire. Comparisons are made to test the significance of any differences in prevalence rates between boys and girls and between each country and the others.

\section{Participants}

\section{Methods}

A total of 4,847 students (50.9\% girls), aged between 7 and 19 years $(M=13.4, S D=2.01)$, from eight European countries, Italy $(N=906)$, Spain $(N=678)$, France $(N=866)$, Poland $(N=810)$, Hungary $(N=624)$, Cyprus $(N=355)$ Bulgaria $(N=276)$, and Greece $(N=332)$ participated in this study. They were drawn from three educational levels: primary schools $(M=9.69, S D=0.59)$, middle schools $(M=12.50$, $S D=1.00)$, and high schools or technical or professional institutes $(M=15.43, S D=1.21)$. The different numbers of schools in the different countries was due to funding and availability. Schools were urban or suburban; no rural schools took part in the study.

The Italian sample was collected from 6 schools $(2$ middle schools, 2 high schools, and 2 technical/professional institutes) located in Naples and the surrounding provinces (Southern Italy). The Spanish sample was recruited from 8 comprehensive schools (primary and middle schools) located in the area of Madrid. In France, there were 12 schools (5 primary schools and 7 secondary schools) located in Nice. The Polish sample was collected from 6 schools located in Bydgoszcz (3 primary and 3 secondary schools). In Hungary, students were recruited from 5 schools ( 2 middle schools and 3 high schools) located in Budapest, Nyíregyháza, Ócsa, and Tiszafüred. The Bulgarian sample was collected from 6 schools (2 comprehensive schools, 3 middle schools and 1 high school) in Sofia, Sillistra, and Burgas. In Cyprus 4 comprehensive schools were recruited in Nicosia and Larnaca. Greek students were recruited from 5 middle schools located in Thessaloniki, Athens, and Sérres. The schools were representative of the types of schools for students aged 7-18 (primary, middle, and high schools), although schools were not randomly selected.

\section{Instruments}

The instrument used was the Tabby online questionnaire, developed as part of the Tabby project and used in several studies (Baldry et al., 2018; Baldry et al., 2017). To measure Cyberbullying and Cybervictimization, the typology of cyberbullying developed by Willard (2007) was used. This typology includes flaming (e.g., an online fight), denigration (e.g., sending or posting cruel gossip or rumors about the victim to damage his/her reputation), impersonation (e.g., posing as the victim and electronically communicating harmful or inappropriate information to others as if it was coming from the victim), outing and trickery (e.g., soliciting personal information from someone and then electronically sharing that information with others without the individual's consent), and exclusion (e.g., blocking an individual from buddy lists). The Tabby online questionnaire also includes other measures, some of which were used for the current study. These include socio-demographic information, use of the Internet (number of hours spent online), the presence of at least a social network profile, and direct knowledge of those who are contacted online.

To measure cyberbullying, and in accordance with what Thomas, Connor, and Scott (2014) and Kowalski et al. (2014) concluded in their reviews, it is preferable to use multiple items instead of a single one that might not capture the complexity and variety of cyberbullying even when a definition has been 
previously provided (Menesini et al., 2012). Cyberbullying was measured using five items (flaming, denigration, impersonation, outing and trickery, and exclusion) that could have occurred in the previous six months. Students could answer on a 5-point Likert scale, with responses ranging from 0 (never happened), 1 (only once or twice), 2 (sometimes), 3 (about once a week), to 4 (several times a week). Example items were: "I pretended to be someone else, created a fake profile in order to send or post damaging messages about another person", "I disclosed online private information or images without the person's consent", and "I was actively engaged in excluding someone from an online group".

To measure cybervictimization, the same criteria were adopted. The same five items were used concerning the previous six months. To have single measures of cyberbullying and cybervictimization, two subscales were created for each country, measuring cyberbullying (total $\alpha=.77$ ) and the cybervictimization (total $\alpha=.71$ ). The two scales were also dichotomized into sometimes or more often versus once or twice or never.

\section{Procedure}

In all the eight participating countries, the same procedure and methodology were adopted; these had been discussed previously during a three-day workshop training. During the meeting, the first version of the questionnaire developed in English was presented, the possible cultural and linguistic differences were addressed, and then it was translated by native speaker researchers of each country into each of the other languages (Cyprus and Greece shared the same language), and back translated against the original. Data were collected during 2014 - 2015, following custodial adults' consent and the approval of the institutional ethics committees in each country.

In each of the participating countries, students were approached in their classes by a junior and senior researcher from that country and then moved to the computer technology room (ITT), that all participating schools had available, to fill in the questionnaire. All students were seated in front of their own PC connected to the website containing the online questionnaire. They were told that they should fill in an online, anonymous self-report questionnaire regarding their experiences with the new communication technologies in the previous six months and that, if they wanted, they could withdraw and be involved in some other activities. No student withdrew from the study, and all participants completed the survey.

Students were also assured about the confidentiality of the study and the anonymity of the answers provided and that no one but the researchers could have access to the responses that, once provided, would automatically go into a database for subsequent aggregated analysis. Students filled in the questionnaire in the presence of a researcher and a teacher who monitored the data collection. They were given the opportunity to pose questions. The average duration of the data collection was 25 minutes.

\section{Data analysis}

Data analyses were carried out using the SPSS statistical package (version 21.0). First, cross-country gender differences in cyberbullying and cybervictimization were examined. Then, involvement in cyberbullying and cybervictimization was separately analyzed for boys and girls by comparing each country with all other countries. For all the analyses performed, and to investigate gender differences, odds ratios were used to measure strengths of relationships because (unlike chi-squared, for example) they are not influenced by sample size (Baldry et al., 2016). 


\section{Descriptive analysis}

\section{Results}

Characteristic of the sample are described in Table 2, showing gender and age distributions as well as providing information about the use of the Internet.

Girls were slightly more represented than boys in Hungary, but in all other countries the distribution was relatively even between boys and girls. At the time of the data collection, the information provided by students regarding their online habits revealed some country differences, with French students reporting the lowest rate $(64.9 \%)$ of students having at least one social network profile, and Hungarian students reporting the highest rate $(93.5 \%)$. While $75 \%$ of all Bulgarian students said that they knew personally all or almost all of their online contacts, Polish and Spanish students reported personally knowing all or nearly all of their contacts in $89.2 \%$ and $89.1 \%$ of cases respectively. Concerning the average estimated hours spent online not for study purposes, the students reporting the highest number of hours were from Bulgaria (30.1\% reported at least five hours a day), and the lowest were from Italy, with $12.6 \%$ of all students reporting being online for five or more hours a day.

Table 2. Descriptive statistics of the sample

\begin{tabular}{|c|c|c|c|c|c|c|c|c|c|c|}
\hline & & $\begin{array}{l}\text { Overall } \\
(N=4,847)\end{array}$ & $\begin{array}{l}\text { Italy } \\
(N=906)\end{array}$ & $\begin{array}{l}\text { France } \\
(N=866)\end{array}$ & $\begin{array}{l}\text { Poland } \\
(N=810)\end{array}$ & $\begin{array}{l}\text { Spain } \\
(N=678)\end{array}$ & $\begin{array}{l}\text { Hungary } \\
(N=624)\end{array}$ & $\begin{array}{l}\text { Cyprus } \\
(N=355)\end{array}$ & $\begin{array}{l}\text { Greece } \\
(N=332)\end{array}$ & $\begin{array}{l}\text { Bulgaria } \\
(N=276)\end{array}$ \\
\hline \multirow[t]{2}{*}{ Gender } & Male & 49.1 & 50.0 & 49.1 & 48.1 & 53.8 & 40.7 & 54.6 & 50.0 & 47.8 \\
\hline & Female & 50.9 & 50.0 & 50.9 & 51.9 & 46.2 & 59.3 & 45.4 & 50.0 & 52.2 \\
\hline Mean age & & $\begin{array}{l}13.4 \\
(S D= \\
2.01)\end{array}$ & $\begin{array}{c}14.8 \\
(S D= \\
2.17) \\
\end{array}$ & $\begin{array}{c}12.3 \\
(S D= \\
1.64)\end{array}$ & $\begin{array}{l}12.2 \\
(S D= \\
1.71) \\
\end{array}$ & $\begin{array}{c}13.2 \\
(S D= \\
1.81)\end{array}$ & $\begin{array}{c}14.7 \\
(S D= \\
1.48) \\
\end{array}$ & $\begin{array}{c}12.9 \\
(S D= \\
1.21) \\
\end{array}$ & $\begin{array}{l}13.8 \\
(S D= \\
0.47) \\
\end{array}$ & $\begin{array}{l}13.3 \\
(S D= \\
2.18) \\
\end{array}$ \\
\hline \multirow{2}{*}{$\begin{array}{l}\text { Profile on a } \\
\text { social } \\
\text { network }\end{array}$} & No & 19.2 & 18.3 & 35.1 & 20.0 & 15.2 & 6.5 & 15.2 & 11.7 & 22.8 \\
\hline & $\begin{array}{r}\text { Yes, one or } \\
\text { more }\end{array}$ & 80.8 & 81.7 & 64.9 & 80.0 & 84.8 & 93.5 & 84.8 & 88.3 & 77.2 \\
\hline \multirow{2}{*}{$\begin{array}{l}\text { Do you } \\
\text { know } \\
\text { personally } \\
\text { all of your } \\
\text { friends on } \\
\text { Internet? }\end{array}$} & $\begin{array}{r}\text { Only } \\
\text { few/half }\end{array}$ & 17.9 & 24.6 & 18.1 & 10.8 & 10.9 & 15.1 & 18.0 & 22.9 & 25.0 \\
\hline & $\begin{array}{r}\text { The major- } \\
\text { ity/all }\end{array}$ & 82.1 & 75.4 & 81.9 & 89.2 & 89.1 & 84.9 & 82.0 & 77.1 & 75.0 \\
\hline \multirow{2}{*}{$\begin{array}{l}\text { Hours } \\
\text { online per } \\
\text { day }\end{array}$} & $0-4$ & 80.3 & 87.4 & 78.7 & 82.3 & 74.8 & 75.0 & 80.3 & 90.1 & 69.9 \\
\hline & $>4$ & 19.7 & 12.6 & 21.3 & 17.7 & 25.2 & 25.0 & 19.7 & 9.9 & 30.1 \\
\hline
\end{tabular}

Notes: $S D=$ standard deviation.

\section{Gender differences in cyberbullying and cybervictimization}

The next step in the analysis was to investigate any significant gender differences within each country concerning all the types of cyberbullying and victimization, using odds ratios. Overall, in all countries, boys were more involved than girls in all types of cyberbullying, but these differences were particularly evident in certain countries.

Table 3 shows that, concerning 'flaming' in Italy, Hungary, and Cyprus, boys were more likely to report perpetrating this conduct online. Concerning 'denigration', significant gender differences were only evident for Italy, with boys being almost twice as likely as girls to be involved. Concerning 'impersonation', gender differences show that boys were up to four times more involved in Italy, Poland, 
Table 3. Gender differences in cyberbullying involvement across countries

\begin{tabular}{|c|c|c|c|c|c|c|c|c|c|c|c|c|c|c|c|c|c|c|c|}
\hline \multirow[b]{2}{*}{ Flaming } & & \multicolumn{2}{|c|}{$\begin{array}{c}\text { Overall } \\
(N=4,847)\end{array}$} & \multicolumn{2}{|c|}{$\begin{array}{c}\text { Italy } \\
(N=906)\end{array}$} & \multicolumn{2}{|c|}{$\begin{array}{c}\text { France } \\
(N=866)\end{array}$} & \multicolumn{2}{|c|}{$\begin{array}{c}\text { Poland } \\
(N=810)\end{array}$} & \multicolumn{2}{|c|}{$\begin{array}{c}\text { Spain } \\
(N=678)\end{array}$} & \multicolumn{2}{|c|}{$\begin{array}{l}\text { Hungary } \\
(N=624)\end{array}$} & \multicolumn{2}{|c|}{$\begin{array}{c}\text { Cyprus } \\
(N=355)\end{array}$} & \multicolumn{2}{|c|}{$\begin{array}{c}\text { Greece } \\
(N=332)\end{array}$} & \multicolumn{2}{|c|}{$\begin{array}{l}\text { Bulgaria } \\
(N=276)\end{array}$} \\
\hline & & $\mathrm{M}$ & $\mathrm{F}$ & $\mathrm{M}$ & $\mathrm{F}$ & $\mathrm{M}$ & $\mathrm{F}$ & $\mathrm{M}$ & $\mathrm{F}$ & $\mathrm{M}$ & $\mathrm{F}$ & $\mathrm{M}$ & $\mathrm{F}$ & $\mathrm{M}$ & $\mathrm{F}$ & $\mathrm{M}$ & $\mathrm{F}$ & $\mathrm{M}$ & $\mathrm{F}$ \\
\hline & $\mathrm{N}$ & 233 & 149 & 55 & 32 & 44 & 32 & 42 & 35 & 22 & 12 & 25 & 19 & 17 & 5 & 11 & 4 & 17 & 10 \\
\hline & $\%$ & 9.8 & 6.0 & 12.1 & 7.1 & 10.4 & 7.3 & 10.8 & 8.3 & 6.0 & 3.8 & 9.8 & 5.1 & 8.8 & 3.1 & 6.6 & 2.4 & 12.9 & 6.9 \\
\hline & $\begin{array}{c}\text { OR } \\
\text { (C.I.) }\end{array}$ & \multicolumn{2}{|c|}{$\begin{array}{c}1.69 * * * \\
(1.36-2.09)\end{array}$} & \multicolumn{2}{|c|}{$\begin{array}{c}1.81^{*} \\
(1.15-2.87)\end{array}$} & \multicolumn{2}{|c|}{$\begin{array}{c}1.48 \\
(0.92-2.38)\end{array}$} & \multicolumn{2}{|c|}{$\begin{array}{c}1.33 \\
(0.83-2.13)\end{array}$} & \multicolumn{2}{|c|}{$\begin{array}{c}1.61 \\
(0.78-3.31)\end{array}$} & \multicolumn{2}{|c|}{$\begin{array}{c}2.02^{*} \\
(1.09-3.75)\end{array}$} & \multicolumn{2}{|c|}{$\begin{array}{c}3.00 * \\
(1.08-8.31)\end{array}$} & \multicolumn{2}{|c|}{$\begin{array}{c}2.87 \\
(0.89-9.21) \\
\end{array}$} & \multicolumn{2}{|c|}{$\begin{array}{c}1.98 \\
(0.87-4.50) \\
\end{array}$} \\
\hline \multicolumn{20}{|l|}{ Denigration } \\
\hline & $\mathrm{N}$ & 155 & 94 & 51 & 27 & 17 & 12 & 17 & 9 & 7 & 4 & 24 & 22 & 8 & 3 & 11 & 5 & 20 & 12 \\
\hline & $\%$ & 6.5 & 3.8 & 11.3 & 6.0 & 4.0 & 2.7 & 4.4 & 2.1 & 1.9 & 1.3 & 9.4 & 5.9 & 4.1 & 1.9 & 6.6 & 3.0 & 15.2 & 8.3 \\
\hline & $\begin{array}{c}\text { OR } \\
\text { (C.I.) }\end{array}$ & \multicolumn{2}{|c|}{$\begin{array}{c}1.76 * * * \\
(1.35-2.29)\end{array}$} & \multicolumn{2}{|c|}{$\begin{array}{c}2.00 * \\
(1.23-3.25) \\
\end{array}$} & \multicolumn{2}{|c|}{$\begin{array}{c}1.49 \\
(0.70-3.16)\end{array}$} & \multicolumn{2}{|c|}{$\begin{array}{c}2.08 \\
(0.92-4.73)\end{array}$} & \multicolumn{2}{|c|}{$\begin{array}{c}1.51 \\
(0.44-5.21) \\
\end{array}$} & \multicolumn{2}{|c|}{$\begin{array}{c}1.65 \\
(0.90-3.01) \\
\end{array}$} & \multicolumn{2}{|c|}{$\begin{array}{c}2.26 \\
(0.59-8.68) \\
\end{array}$} & $\begin{array}{r}2 . \\
(0.78\end{array}$ & 73) & $(0.9$ & 19) \\
\hline Impersonation & & & & & & & & & & & & & & & & & & & \\
\hline & $\mathrm{N}$ & 113 & 50 & 34 & 10 & 16 & 10 & 15 & 4 & 3 & 4 & 15 & 13 & 4 & 0 & 9 & 2 & 17 & 7 \\
\hline & $\%$ & 4.7 & 2.0 & 7.5 & 2.2 & 3.8 & 2.3 & 3.8 & 1.0 & 0.8 & 1.3 & 5.9 & 3.5 & 2.1 & 0.0 & 5.4 & 1.2 & 12.9 & 4.9 \\
\hline & $\begin{array}{l}\text { OR } \\
\text { (C.I.) }\end{array}$ & $\begin{array}{r}2.4 \\
(1.72\end{array}$ & ** 38$)$ & $\begin{array}{r}3 . \\
(1.7\end{array}$ & 37) & $\begin{array}{r}1 \\
(0.76\end{array}$ & 76) & $\begin{array}{r}4 \\
(1.37\end{array}$ & $64)$ & & $2.88)$ & $(0.8$ & $2.69)$ & Not ca & lable & $\begin{array}{r}4 . \\
(1.00\end{array}$ & 10) & $\begin{array}{r}2 \\
(1.1\end{array}$ & 22) \\
\hline Outing & & & & & & & & & & & & & & & & & & & \\
\hline & $\mathrm{N}$ & 127 & 62 & 27 & 6 & 17 & 9 & 13 & 6 & 10 & 10 & 26 & 13 & 8 & 4 & 9 & 3 & 17 & 11 \\
\hline & $\%$ & 5.3 & 2.5 & 6.0 & 1.3 & 4.0 & 2.0 & 3.3 & 1.4 & 2.7 & 3.2 & 10.2 & 3.5 & 4.1 & 2.5 & 5.4 & 1.8 & 12.9 & 7.6 \\
\hline & $\begin{array}{l}\text { OR } \\
\text { (C.I.) }\end{array}$ & $\begin{array}{r}2.1 \\
(1.61\end{array}$ & ** & $\begin{array}{r}4.7 \\
(1.93\end{array}$ & $.55)$ & $\begin{array}{r}2 \\
(0.88\end{array}$ & 54) & $\begin{array}{r}2 \\
(0.8\end{array}$ & 32) & $(0.3$ & $2.08)$ & $\begin{array}{r}3 . \\
(1.5\end{array}$ & 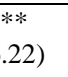 & $\begin{array}{r}1 \\
(0.50\end{array}$ & & $\begin{array}{r}3 . \\
(0.83\end{array}$ & .72) & (0.8 & 97) \\
\hline Exclusion & & & & & & & & & & & & & & & & & & & \\
\hline & $\mathrm{N}$ & 165 & 58 & 33 & 9 & 39 & 11 & 23 & 9 & 16 & 2 & 26 & 15 & 5 & 1 & 6 & 1 & 17 & 10 \\
\hline & $\%$ & 6.9 & 2.4 & 7.3 & 2.0 & 9.2 & 2.5 & 5.9 & 2.1 & 4.4 & 0.6 & 10.2 & 4.1 & 2.6 & 0.6 & 3.6 & 0.6 & 12.9 & 6.9 \\
\hline & $\begin{array}{l}\text { OR } \\
\text { (C.I.) }\end{array}$ & $\begin{array}{r}3.11 \\
(2.28\end{array}$ & *** & $\begin{array}{r}3.8 \\
(1.8 \\
\end{array}$ & *** & $\begin{array}{r}3.9 \\
(1.99\end{array}$ & . 82 & $\begin{array}{r}2.8 \\
(1.3\end{array}$ & (26) & $\begin{array}{r}7 \\
(1.6 \\
\end{array}$ & $\begin{array}{l}* * \\
1.25)\end{array}$ & $\begin{array}{r}2 . \\
(1.4\end{array}$ & .21) & $\begin{array}{r}4 \\
(0.45 \\
\end{array}$ & $60)$ & $\begin{array}{r}6 . \\
(0.74\end{array}$ & $97)$ & $(0.8$ & 50) \\
\hline Total Cyber & & & & & & & & & & & & & & & & & & & \\
\hline bullying & $\mathrm{N}$ & 421 & 269 & 109 & 62 & 71 & 44 & 55 & 42 & 36 & 22 & 68 & 53 & 25 & 12 & 25 & 12 & 32 & 22 \\
\hline & $\%$ & 17.7 & 10.9 & 24.1 & 13.7 & 16.7 & 10.0 & 14.1 & 10.0 & 9.9 & 7.0 & 26.8 & 14.3 & 12.9 & 7.5 & 15.1 & 7.2 & 24.2 & 15.3 \\
\hline & $\begin{array}{l}\text { OR } \\
\text { (C.I.) }\end{array}$ & $\begin{array}{r}1.7 \\
(1.49\end{array}$ & *** & $\begin{array}{r}1.9 \\
(1.4\end{array}$ & *** & $\begin{array}{r}1.8 \\
(1.21\end{array}$ & * 71$)$ & $\begin{array}{r}1 . \\
(0.96\end{array}$ & 27) & $(0.8$ & $\begin{array}{l}5.52) \\
5\end{array}$ & $\begin{array}{r}2 . \\
(1.4\end{array}$ & *** & $\begin{array}{r}1 \\
(0.89\end{array}$ & & $\begin{array}{r}2.2 \\
(1.10\end{array}$ & & $\begin{array}{r}1 \\
(0.9\end{array}$ & 25) \\
\hline
\end{tabular}

Notes. ${ }^{\dagger} p<.10 ; * p<.05 ; * * p<.01 ; * * * p<.00$

$\mathrm{OR}=$ Odds Ratio; C.I. $=$ Confidence Interval 
Table 4. Gender differences in cybervictimization involvement across countries

\begin{tabular}{|c|c|c|c|c|c|c|c|c|c|c|c|c|c|c|c|c|c|c|c|}
\hline & & \multicolumn{2}{|c|}{$\begin{array}{l}\text { Overall } \\
(N=4,847)\end{array}$} & \multicolumn{2}{|c|}{$\begin{array}{l}\text { Italy } \\
(N=906)\end{array}$} & \multicolumn{2}{|c|}{$\begin{array}{l}\text { France } \\
(N=866)\end{array}$} & \multicolumn{2}{|c|}{$\begin{array}{l}\text { Poland } \\
(N=810)\end{array}$} & \multicolumn{2}{|c|}{$\begin{array}{l}\text { Spain } \\
(N=678)\end{array}$} & \multicolumn{2}{|c|}{$\begin{array}{l}\text { Hungary } \\
(N=624)\end{array}$} & \multicolumn{2}{|c|}{$\begin{array}{l}\text { Cyprus } \\
(N=355) \\
\end{array}$} & \multicolumn{2}{|c|}{$\begin{array}{l}\text { Greece } \\
(N=332)\end{array}$} & \multicolumn{2}{|c|}{$\begin{array}{l}\text { Bulgaria } \\
(N=276)\end{array}$} \\
\hline & & $\mathrm{M}$ & $\mathrm{F}$ & $\mathrm{M}$ & $\mathrm{F}$ & $\mathrm{M}$ & $\mathrm{F}$ & $\mathrm{M}$ & $\mathrm{F}$ & $\mathrm{M}$ & $\mathrm{F}$ & $\mathrm{M}$ & $\mathrm{F}$ & $\mathrm{M}$ & $F$ & $\mathrm{M}$ & $\mathrm{F}$ & $\mathrm{M}$ & $\mathrm{F}$ \\
\hline \multirow{3}{*}{ Flaming } & $\mathrm{N}$ & 151 & 140 & 36 & 44 & 26 & 32 & 28 & 15 & 14 & 13 & 9 & 15 & 11 & 7 & 9 & 3 & 18 & 11 \\
\hline & $\%$ & 6.3 & 5.7 & 7.9 & 9.7 & 6.1 & 7.3 & 7.2 & 3.6 & 3.8 & 4.2 & 3.5 & 4.1 & 5.7 & 4.3 & 5.4 & 1.8 & 13.6 & 7.6 \\
\hline & $\begin{array}{l}\text { OR } \\
\text { (C.I.) }\end{array}$ & \multicolumn{2}{|c|}{$\begin{array}{c}1.13 \\
(0.89-1.43)\end{array}$} & \multicolumn{2}{|c|}{$\begin{array}{c}0.80 \\
(0.51-1.27)\end{array}$} & \multicolumn{2}{|c|}{$\begin{array}{c}0.83 \\
(0.49-1.42)\end{array}$} & \multicolumn{2}{|c|}{$\begin{array}{c}2.09^{*} \\
(1.09-3.97)\end{array}$} & \multicolumn{2}{|c|}{$\begin{array}{c}0.92 \\
(0.43-1.99)\end{array}$} & \multicolumn{2}{|c|}{$\begin{array}{c}0.87 \\
(0.37-2.02)\end{array}$} & \multicolumn{2}{|c|}{$\begin{array}{c}1.32 \\
(0.50-3.49)\end{array}$} & \multicolumn{2}{|c|}{$\begin{array}{c}3.11 \\
(0.83-11.72)\end{array}$} & \multicolumn{2}{|c|}{$\begin{array}{c}1.91 \\
(0.87-4.21)\end{array}$} \\
\hline \multirow{3}{*}{ Denigration } & $\mathrm{N}$ & 139 & 146 & 22 & 18 & 27 & 46 & 22 & 14 & 7 & 8 & 13 & 16 & 16 & 15 & 10 & 16 & 22 & 13 \\
\hline & $\%$ & 5.8 & 5.9 & 4.9 & 4.0 & 6.4 & 10.4 & 5.6 & 3.3 & 1.9 & 2.6 & 5.1 & 4.3 & 8.2 & 9.3 & 6.0 & 9.6 & 16.7 & 9.0 \\
\hline & $\begin{array}{l}\text { OR } \\
\text { (C.I.) }\end{array}$ & \multicolumn{2}{|c|}{$\begin{array}{c}0.99 \\
(0.78-1.25)\end{array}$} & \multicolumn{2}{|c|}{$\begin{array}{c}1.23 \\
(0.65-2.33)\end{array}$} & \multicolumn{2}{|c|}{$\begin{array}{c}0.58^{*} \\
(0.35-0.96)\end{array}$} & \multicolumn{2}{|c|}{$\begin{array}{c}1.73 \\
(0.87-3.44)\end{array}$} & \multicolumn{2}{|c|}{$\begin{array}{c}0.74 \\
(0.27-2.08)\end{array}$} & \multicolumn{2}{|c|}{$\begin{array}{c}1.99 \\
(0.56-2.53)\end{array}$} & \multicolumn{2}{|c|}{$\begin{array}{c}0.87 \\
(0.42-1.83)\end{array}$} & \multicolumn{2}{|c|}{$\begin{array}{c}0.60 \\
(0.26-1.37)\end{array}$} & \multicolumn{2}{|c|}{$\begin{array}{c}2.01 \\
(0.97-4.19)\end{array}$} \\
\hline & $\mathrm{N}$ & 116 & 122 & 32 & 29 & 17 & 30 & 15 & 8 & 7 & 5 & 12 & 21 & 13 & 2 & 6 & 9 & 14 & 18 \\
\hline & $\%$ & 4.9 & 4.9 & 7.1 & 6.4 & 4.0 & 6.8 & 3.8 & 1.9 & 1.9 & 1.6 & 4.7 & 5.7 & 6.7 & 1.2 & 3.6 & 5.4 & 10.6 & 12.5 \\
\hline Impersonation & $\begin{array}{l}\text { OR } \\
\text { (C.I.) }\end{array}$ & & $\begin{array}{l}99 \\
1.28)\end{array}$ & & $\begin{array}{l}1 \\
1.87)\end{array}$ & & $\begin{array}{l}57 \\
-1.05)\end{array}$ & $(0.8$ & $\begin{array}{l}06 \\
-4.91)\end{array}$ & & $3.83)$ & $(0.4$ & $\begin{array}{l}82 \\
1.71)\end{array}$ & $(1.2$ & $\begin{array}{l}1 * \\
25.69)\end{array}$ & & $\begin{array}{l}65 \\
1.88)\end{array}$ & $(0.3$ & $\begin{array}{l}3 \\
1.74)\end{array}$ \\
\hline & $\mathrm{N}$ & 135 & 127 & 28 & 18 & 21 & 32 & 20 & 16 & 6 & 8 & 18 & 22 & 15 & 12 & 10 & 12 & 17 & 7 \\
\hline & $\%$ & 5.7 & 5.1 & 6.2 & 4.0 & 4.9 & 7.3 & 5.1 & 3.8 & 1.6 & 2.6 & 7.1 & 5.9 & 7.7 & 7.5 & 6.0 & 7.2 & 12.9 & 4.9 \\
\hline Outıng & $\begin{array}{l}\text { OR } \\
\text { (C.I.) }\end{array}$ & & $\begin{array}{l}11 \\
-1.42)\end{array}$ & & $\begin{array}{l}50 \\
2.92)\end{array}$ & & $\begin{array}{l}66 \\
-1.17)\end{array}$ & & $\begin{array}{l}36 \\
2.67)\end{array}$ & & $\begin{array}{l}64 \\
1.86)\end{array}$ & & $\begin{array}{l}21 \\
2.30)\end{array}$ & & $\begin{array}{l}4 \\
2.92)\end{array}$ & $(0.3$ & $\begin{array}{l}82 \\
-1.96)\end{array}$ & $\begin{array}{r}2 \\
(1.1\end{array}$ & $\begin{array}{l}* \\
7.22)\end{array}$ \\
\hline & $\mathrm{N}$ & 136 & 107 & 24 & 22 & 29 & 14 & 21 & 11 & 9 & 9 & 9 & 24 & 13 & 5 & 5 & 9 & 26 & 13 \\
\hline & $\%$ & 5.7 & 4.3 & 5.3 & 4.9 & 6.8 & 3.2 & 5.4 & 2.6 & 2.5 & 2.9 & 3.5 & 6.5 & 6.7 & 3.1 & 3.0 & 5.4 & 19.7 & 9.0 \\
\hline Exclusion & $\begin{array}{l}\text { OR } \\
\text { (C.I.) }\end{array}$ & & $\begin{array}{l}3 * \\
-1.73)\end{array}$ & & $\begin{array}{l}9 \\
1.98)\end{array}$ & & $\begin{array}{l}3^{*} \\
-4.29)\end{array}$ & & $\begin{array}{l}2^{*} \\
-4.45)\end{array}$ & & $\begin{array}{l}5 \\
2.18)\end{array}$ & & $\begin{array}{l}53 \\
-1.16)\end{array}$ & & $\begin{array}{l}24 \\
-6.42)\end{array}$ & & $\begin{array}{l}54 \\
1.65)\end{array}$ & & $\begin{array}{l}7^{*} \\
5.04)\end{array}$ \\
\hline & $\mathrm{N}$ & 393 & 404 & 81 & 93 & 75 & 84 & 45 & 36 & 31 & 26 & 37 & 65 & 34 & 27 & 29 & 33 & 61 & 40 \\
\hline & $\%$ & 16.5 & 16.4 & 17.9 & 20.5 & 17.6 & 19.0 & 11.5 & 8.6 & 8.5 & 8.3 & 14.6 & 17.6 & 17.5 & 16.8 & 17.5 & 19.9 & 46.2 & 27.8 \\
\hline victimization & $\begin{array}{l}\text { OR } \\
\text { (C.I.) }\end{array}$ & & $\begin{array}{l}01 \\
-1.18)\end{array}$ & & $\begin{array}{l}84 \\
1.17)\end{array}$ & $(0.6$ & $\begin{array}{l}91 \\
-1.29)\end{array}$ & & $\begin{array}{l}39 \\
2.21)\end{array}$ & & $\begin{array}{l}3 \\
1.77)\end{array}$ & $(0.5$ & $\begin{array}{l}80 \\
-1.24)\end{array}$ & & $\begin{array}{l}06 \\
-1.84)\end{array}$ & & $\begin{array}{l}55 \\
1.48)\end{array}$ & $\begin{array}{r}2 \\
(1.3\end{array}$ & 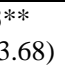 \\
\hline
\end{tabular}

Notes. ${ }^{\dagger} p<.10 ; * p<.05 ; * * p<.01 ; * * * p<.001$

$\mathrm{OR}=$ Odds Ratio

C.I. = Confidence Interval 
Greece, and Bulgaria. With regard to 'outing', boys were between almost five times and two times more likely to be involved, respectively, in Italy and Hungary. Concerning 'excluding' someone, Spanish, French, Italian, Polish, and Hungarian students were between two and eight times more likely to be involved than girls.

Concerning different types of cybervictimization, there were fewer gender differences. Overall, boys and girls were equally victimized. In Poland, boys reported being a victim of flaming twice as much as girls. In France, boys were less likely than girls to be victimized by denigration, whereas in Cyprus boys were more than six times as likely to be victims of impersonation compared to girls. In Bulgaria, boys were twice as likely to be victims of outing and, in France and Bulgaria, boys were excluded twice as often as girls.

\section{Cross-country comparisons of cyberbullying and cybervictimization}

Separately, involvement of boys and girls in cyberbullying and cybervictimization was compared for each country against all other countries by calculating odds ratios. Table 5 compares the total measures of cyberbullying and cybervictimization for each country against the rest. Concerning cyberbullying, Italian, Hungarian, and Bulgarian boys were more likely than boys in the other countries to perform such behaviors. French, Polish, Spanish, Cypriot, and Greek girls were less likely to cyberbully others, compared to the other countries. Concerning cybervictimization, Spanish boys were less likely to be cybervictims, whereas Bulgarian boys were much more likely to be cybervictimized. Bulgarian and Italian girls were more likely to be cybervictimized, whereas Polish and Spanish girls were much less likely.

Table 5. Comparison of cyberbullying and cybervictimization for each country against the rest

\begin{tabular}{|c|c|c|c|c|c|c|c|c|c|}
\hline & & $\begin{array}{c}\text { Italy } \\
(N=906)\end{array}$ & $\begin{array}{c}\text { France } \\
(N=866)\end{array}$ & $\begin{array}{c}\text { Poland } \\
(N=810)\end{array}$ & $\begin{array}{c}\text { Spain } \\
(N=678)\end{array}$ & $\begin{array}{l}\text { Hungary } \\
(N=624)\end{array}$ & $\begin{array}{c}\text { Cyprus } \\
(N=355)\end{array}$ & $\begin{array}{c}\text { Greece } \\
(N=332)\end{array}$ & $\begin{array}{l}\text { Bulgaria } \\
(N=276)\end{array}$ \\
\hline \multirow{2}{*}{ Male } & $\%$ & 24.2 & 16.7 & 14.1 & 9.9 & 26.8 & 12.9 & 15.1 & 24.2 \\
\hline & $\begin{array}{l}\text { OR } \\
\text { CB }\end{array}$ & $2.10 * * *$ & 1.23 & 0.99 & $0.64 *$ & $2.33^{* * *} *$ & 0.89 & 1.07 & $1.97 * * *$ \\
\hline \multirow{2}{*}{ Female } & $\%$ & 13.6 & 10.0 & 10.0 & 7.0 & 14.3 & 7.5 & 7.2 & 15.3 \\
\hline & $\begin{array}{l}\text { OR } \\
\text { CB }\end{array}$ & 0.93 & $0.64 * *$ & $0.65^{* * *}$ & $0.44 * * *$ & 1.01 & $0.48 *$ & $0.46 *$ & 1.09 \\
\hline \multirow{2}{*}{ Male } & $\%$ & 17.8 & 17.6 & 11.5 & 8.5 & 14.6 & 17.5 & 17.5 & 46.2 \\
\hline & $\begin{array}{l}\mathrm{OR} \\
\mathrm{CV}\end{array}$ & 1.11 & 1.10 & $.64 * *$ & $.45^{* * * *}$ & .86 & 1.08 & 1.08 & $4.64 * * *$ \\
\hline \multirow[t]{2}{*}{ Female } & $\%$ & 20.7 & 19.0 & 8.6 & 8.3 & 17.6 & 16.8 & 19.9 & 27.8 \\
\hline & $\begin{array}{l}\text { OR } \\
\mathrm{CV} \\
\end{array}$ & $1.37 *$ & 1.22 & $0.45^{* * *}$ & $0.44 * * *$ & 1.09 & 1.02 & 1.27 & $2.00 * * *$ \\
\hline
\end{tabular}

Notes. ${ }^{\dagger} p<.10 ; * p<.05 ; * * p<.01 ; * * * p<.001$

OR CB = Odds Ratio for cyberbullying; OR CV= Odds Ratio for cybervictimization.

\section{Number of hours online versus cyberbullying and cybervictimization}

Being frequently online is an important risk factor for cyberbullying and cybervictimization. Over all countries, boys who spent more than four hours online per day were about twice as likely to become cyberbullies (32.6\% versus $14.1 \%$; odds ratio or $\mathrm{OR}=2.94,95 \%$ confidence interval or CI 2.33-3.72) and cybervictims $(27.0 \%$ versus $14.0 \%$; OR $=2.26$, CI 1.77-2.89). Similarly, girls who spent more than four hours online per day were about twice as likely to become cyberbullies $(20.6 \%$ versus $8.5 \%$; OR $=2.81$, CI 2.14-3.67) and cybervictims (23.6\% versus $14.5 \%$; OR $=1.82$, CI $1.43-2.32)$.

\section{Discussion}

Across the globe, the Internet has become an integral, accessible, and relatively cheap way for young people to communicate, to gather information and to obtain entertainment, as well as to gain popularity, 
especially among adolescents (Tsitsika et al., 2009; 2015). However, Internet use carries specific risks, including cyberbullying and cybervictimization.

The current study compared cyberbullying and cybervictimization across eight European countries to establish prevalence rates and significant national differences concerning types of behaviors and gender. The difficulty in comparing results between countries and between studies has often been caused by the different methodologies and measures used. Some of the limitations of previous studies were present also in the current research. Cyberbullying and cybervictimization were based on self-reports and, as with other cross-sectional studies, no causal conclusions can be drawn from the results. As with other cross-national studies, there could still be differences in the meaning of words, although back translations by experts minimized this risk. The different sample sizes between countries and sampling procedures could have affected which schools eventually participated in the study.

In spite of these limitations, the Tabby project conducted in Europe with the same open access online questionnaire, yields directly comparable information about the prevalence and nature of cyberbullying and cybervictimization. This online procedure reduces the possible bias of self-report data using traditional pen and pencil surveys, where students have to write their answers, and its better guarantee of anonymity may have encouraged more valid answers.

Overall, more than one in four adolescents reported being a victim of cyberbullying in the previous six months, with boys globally more involved than girls. Compared with girls, two to five times as many boys reported cyberbullying. This finding is consistent with those from other studies that have found gender differences in cyberbullying and cybervictimization (Tokunaga, 2010). For example, Kowalski and Limber (2007) reported that, among a middle school sample, boys were more likely to be cyberbullies than girls. Similarly, another study found that significantly more girls were cyberbullied in the past month compared with boys (Dempsey, Sulkowski, \& Nichols, 2009). In our study, we did not find that girls were more likely to be cybervictimized than boys, except in France.

As pointed out by Tsitsika et al. (2015) it is necessary to advance knowledge further about the gender gap in antisocial behavior and in cyberbullying. In school bullying, boys are more likely to be bullies, and girls are more likely to be victims of indirect forms. However, for cyber behavior, boys report more cyberbullying, but across countries, there were no significant gender differences in cybervictimization, or boys were sometimes more involved compared to girls. Based also on our findings, we should also investigate the methods and mechanisms through which girls and boys bully or are victimized online as well as the different forms of victimization online.

One possible explanation of gender differences in prevalence rates between boys and girls in school bullying and cyberbullying is that, as boys tend to be generally more aggressive than girls, girls are more likely to be subjected to aggression by both boys and girls. However, the online work and use of SNSs is more 'gender neutral' when it comes to cybervictimization, meaning that the types of behaviors that constitute cyberbullying are more concerned with verbal abuse or threats. Girls could be more likely to be cybervictimized when it comes to sexting, but we did not include this measure in this study, as the prevalence rates were not included as part of the global measure of cybervictimization and cyberbullying.

Being frequently online and having an SNS account are risk factors for cyberbullying and cybervictimization, as students are more likely to be exposed to the risk (Baldry et al., 2015; Erdur-Baker, 2010). In our study, a high frequency of Internet use (more than 4 hours a day) as well as SNS use in particular (i.e., at least one social network account and not knowing all or almost all contacts), was present more in those countries reporting higher levels of cyberbullying such as Bulgaria. The most likely factor affecting reports of cyberbullying and cybervictimization may be the number of hours spent online. 
Bulgarian students reported a higher number of hours and also had higher rates of cyberbullying. Conversely, Poland had fewer hours and lower rates.

These results are in line with another large-scale European study reporting that those children who were involved either as bullies or victims online were twice as likely to use SNS compared to those who were not involved (Staksrud, Ólafsson, \& Livingstone, 2013). In our study, the Greek, Italian, and Polish students reported spending less hours per day online compared to the others, which could explain in part the lower rates of involvement of both boys and girls in cyberbullying and cybervictimization, especially in Greece (Athanasiades, Kamariotis, Psalti, Baldry, \& Sorrentino, 2015; Livingstone et al., 2011; Tsitsika et al., 2012). The case of Spanish students is interesting, as they reported high rates of SNS use but also low rates of cyberbullying. A possible explanation is that in Spain many prevention programs have been developed in schools and online to increase awareness about the dangerous aspects of the Internet (Zych et al., 2015).

Being online not for study reasons for quite some time during the day and making use of SNS may be considered risk factors for cyberbullying and cybervictimization (Juvonen \& Gross, 2008), especially for adolescents who have access to online communication from their smartphones and, in several locations, mainly from their own rooms with no supervision (Law, Shapka, \& Olson, 2010). The higher numbers of hours that Bulgarian and Hungarian students report spending online, that we found in our study, was reported also in other Eastern European countries in the EU Kids Online study (Livingstone et al., 2011).

Understanding the epidemiology of cyberbullying and cybervictimization across several countries, with regard to types of actions and gender differences, and addressing potential risk factors, is useful to inform the advantages and limitations of implementing global anti-cyberbullying programs. Evaluations of existing programs are encouraging (Gaffney, Farrington, Espelage, \& Ttofi, 2019), but more and better programs are needed. Our large-scale cross-national comparative research should contribute to this effort.

\section{References}

Ang, R. P., Huan, V. S., \& Florell, D. (2013). Understanding the relationship between proactive and reactive aggression and cyberbullying across United States and Singapore adolescent samples. Journal of Interpersonal Violence, 29, 237-254. doi: 10.1177/0886 260513505149.

Ang, R. P., \& Goh, D. H. (2010). Cyberbullying among adolescents: The role of affective and cognitive empathy, and gender. Child Psychiatry and Human Development, 41, 387-397. doi:10.1007/s10578-010-0176-3.

Aoyama, I., Utsumi, S., \& Hasegawa, M. (2012). Cyberbullying in Japan: Cases, government reports, adolescent relational aggression and parental monitoring roles. In Q. Li, D. Cross, \& P. K. Smith (Eds.), Cyberbullying in the global playground: Research from international perspectives (pp. 183-201). Malden, MA: Blackwell.

Athanasiades, C., Kamariotis, H., Psalti, A., Baldry, A. C., \& Sorrentino, A. (2015). Internet use and cyberbullying among adolescent students in Greece: The "Tabby" project. Hellenic Journal of Psychology, 12, 14-39.

Athanasiou, K., Melegkovits, E., Andrie, E. K., Magoulas, C., Tzavara, C. K., Richardson, C., Greydanus, D., Tsolia, M., \& Tsitsika, A. K. (2018). Cross-national aspects of cyberbullying victimization among 14-17-year-old adolescents across seven European countries. BMC Public Health, 18, 800-815. https://doi.org/10.1186/s12889-018-5682-4.

Baldry, A. C., Blaya, C., \& Farrington D. P. (Eds.). (2018). International Perspectives on Cyberbullying: Prevalence, Risk Factors and Interventions. London: Palgrave -MacMillan.

Baldry, A. C., Farrington, D. P., \& Sorrentino, A. (2017). School bullying and cyberbullying among boys and girls: Roles and overlap. Journal of Aggression, Maltreatment and Trauma, 26, 937-951. doi: 10.1080/10926771.2017.1330793.

Baldry, A. C., Farrington, D. P., \& Sorrentino, A. (2016). Bullying and cyberbullying among youngsters: A pattern of disruptive behavior. Psicologia Educativa, 22, 19-26. doi: 10.1016/j.pse.2016.02.001.

Baldry, A. C., Farrington, D. P., \& Sorrentino, A. (2015). “Am I at risk of cyberbullying”? A narrative review and conceptual framework for research on risk of cyberbullying and cybervictimization: The risk and needs assessment approach. Aggression and Violent Behavior, 23, 36-51. doi: 10.1016/j.avb.2015.05.014. 
Barlett, C. P., Gentile, D. A., Anderson, C. A., Suzuki, K., Sakamoto, A., Yamaoka, A., \& Katsura, R. (2014). Crosscultural differences in cyberbullying behavior: A short-term longitudinal study. Journal of Cross-Cultural Psychology, 45, 300-313. doi: 10.1177/002 2022113504622.

Bauman, S., \& Bellmore, A. (2015). New directions in cyberbullying research. Journal of School Violence, 14, 1-10. https://doi.org/10.1080/15388220.2014.968281.

Besley, B. (2009). Cyberbullying. Retrieved from www.cyberbullying.ca.

Blaya, C., Sandaram, S., Kaur, K., \& Damanjit, S. (2016). Digital uses, risk-taking and online negative experiences among secondary school students in France and India: A comparative study. Retrieved from https://hal.archives-ouvertes.fr/hal-01509726/.

Brighi, A., Ortega, R., Pyzalski, J., Scheithauer, H., Smith, P. K., Tsormpatzoudis, H., et al. (2012). European cyberbullying intervention project questionnaire - ECIPQ [Unpublished questionnaire]. Retrieved from www.bullyingandcyber.net.

Calvete, E., Orue, I., Estévez, A., Villardón, L., \& Padilla, P. (2010). Cyberbullying in adolescents: Modalities and aggressors' profile. Computers in Human Behavior, 26, 1128-1135. doi: 10.1016/j.chb.2010.03.017.

Davis, L. J., Hoffman, N. G., Morse, R. M., \& Luehr, J. G. (1992). Substance use disorder diagnostic schedule (SUDDS): The equivalence and validity of a computer-administered and an interviewer-administered format. Alcoholism: Clinical and Experimental Research, 16, 250-254. https://doi.org/10.1111/j.15300277.1992.tb.01371.x.

Del Rey, R., Casas, J. A., Ortega-Ruiz, R., Schultze-Krumbholz, A., Scheithauer, H., Smith, P., Thompson, F., Barkoukis, V., Tsorbatzoudis, H., Brighi, A., Guarini, A., Pyżalski, J., \& Plichta, P. (2015). Structural validation and cross-cultural robustness of the European Cyberbullying Intervention Project Questionnaire. Computers in Human Behavior, 50, 141-147. doi: 10.1016/j.chb.2015.03.065.

Dempsey, A. G., Sulkowski, M. L., Nichols, R., \& Storch, E. A. (2009). Differences between peer victimization in cyber and physical settings and associated psychosocial adjustment in early adolescence. Psychology in the Schools, 46, 962-972. doi:org/10.1002/pits.20437.

Dooley, J., Pyżalski, J., \& Cross, D. (2009). Cyberbullying versus face to face bullying: A theoretical and conceptual review. Zeitschrift für Psychologie/Journal of Psychology, 217, 182-188. doi: 10.1027/0044-3409.217.4.182.

Erdur-Baker, Ö. (2010). Cyberbullying and its correlation to traditional bullying, gender and frequent and risky usage of internet-mediated communication tools. New Media and Society, 12, 109-125. doi:10.1177/1461444809341260.

Estévez, A., Villardón, L., Calvete, E., Padilla, P., \& Orue, I. (2010). Adolescentes víctimas de cyberbullying: Prevalencia y características. Psicología Conductual, 18, 73-89.

Finkelhor, D., Mitchell, K. J., \& Wolak, J. (2000). Online victimization: A report on the nation's youth. Retrieved from https://files.eric.ed.gov/fulltext/ED442039.pdf.

Gaffney, H., Farrington, D. P., Espelage, D. L., \& Ttofi, M. M. (2019). Are cyberbullying intervention and prevention programs effective? A systematic and meta-analytical review. Aggression and Violent Behavior, 45, $134-153$.

Gamez-Guadix, M., Villa-George, F., \& Calvete, E. (2012). Measurement and analysis of the cognitive-behavioral model of generalized problematic Internet use among Mexican adolescents. Journal of Adolescence, 35, 1581159.

Gámez-Guadix, M., Orue, I., Smith, P. K., \& Calvete, E. (2013). Longitudinal and reciprocal relations of cyberbullying with depression, substance use, and problematic internet use among adolescents. Journal of Adolescent Health, 53, 446-452. doi: 10.1016/j. jadohealth.2013.03.030.

Genta, M. L., Smith, P. K., Ortega-Ruiz, R. Brighi, A., Guarini, A., Thompson, F., \& Calmaestra, J. (2012). Comparative aspects of cyberbullying in Italy, England and Spain: Findings from a DAPHNE Project. In Q. Li, D. Cross, \& P.K. Smith, (Eds.). Cyberbullying in the global playground: Research from international perspectives, (pp. 15 - 31). Chichester, UK: Wiley-Blackwell.

Hasebrink, U., Livingstone, S., \& Haddon, L. (2008). Comparing children's online opportunities and risks across Europe: Cross-national comparisons for EU Kids Online. London: EU Kids Online. Retrived from http://eprints.lse.ac.uk/21656/1/D3.2_Report-Cross_national_comparisons.pdf.

Jaghoory, H., Björkqvist, K., \& Österman, K. (2015). Cyberbullying among adolescents: A comparison between Iran and Finland. Journal of Child and Adolescent Behaviour, 3, 265-272. doi: 10.4172/2375-4494.1000265.

Juvonen, J., \& Gross, E. F. (2008). Extending the school grounds? Bullying experiences in cyberspace. Journal of School Health, 78, 496-505. doi:10.1111/j.1746-1561.2008.00335.x.

Kowalski, R. M., Giumetti, G. W., Schroeder, A. N., \& Lattanner, M. R. (2014). Bullying in the digital age: A critical review and meta-analysis of cyberbullying research among youth. Psychological Bulletin, 140, $1073-1137$. doi: $10.1037 / \mathrm{a} 0035618$. 
Kowalski, R. M., \& Limber, S. P. (2007). Electronic bullying among middle school students. Journal of Adolescent Health, 41, S22-S30. doi: 10.1016/j.jadohealth. 2007.08.017.

Law, D. M., Shapka, J. D., \& Olson, B. F. (2010). To control or not to control? Parenting behaviors and adolescent online aggression. Computers in Human Behavior, 26, 1651-1656. https://doi.org/10.1016/j.chb.2010.06.013.

Lee, C., \& Shin, N. (2017). Prevalence of cyberbullying and predictors of cyberbullying perpetration among Korean adolescents. Computers in Human Behavior, 68, 352-358. doi: 10.1016/j.chb. 2016.11.047.

$\mathrm{Li}, \mathrm{Q}$. (2008). A cross-cultural comparison of adolescents' experience related to cyberbullying. Educational Research, 50, 223-234. doi: 10.1080/00131880802 309333.

Li, Q. (2007). Bullying in the new playground: Research into cyberbullying and cybervictimization. Australasian Journal of Educational Technology, 23, 435-454. doi:org/10.14742/ajet.1245.

Livingstone, S., Haddon, L., Görzig, A., \& Ólafsson, K. (2011). EU Kids Online: Final report. London, UK: EU Kids Online.

Lobe, B., Livingstone, S., Ólafsson, K., \& Vodeb, H. (2011) Cross-national comparison of risks and safety on the internet: Initial analysis from the EU Kids Online survey of European children. London: EU Kids Online.

Menesini, E., Nocentini, A., Palladino, B. E., Frisén, A., Berne, S., Ortega-Ruiz, R., Calmaestra, J., Scheithauer, H., Schultze-Krumbholz, A., Karin, P. L., Naruskov, K., Blaya, C., Berthaud, J., \& Smith, P. K. (2012). Cyberbullying definition among adolescents: A comparison across six European countries. Cyberpsychology, Behavior, and Social Networking, 15, 455-463. doi: 10.1089/ cyber.2012.0040.

Mura, G., Topcu, C., Erdur-Baker, O., \& Diamantini, D. (2011). An international study of cyberbullying perception and diffusion among adolescents. Procedia-Social and Behavioral Sciences, 15, 3805-3809. doi: 10.1016/j.sbspro.2011.04.377.

Nocentini, A., Calmaestra, J., Schultze-Krumbholz, A., Scheithauer, H., Ortega-Ruiz, R., \& Menesini, E. (2010). Cyberbullying: Labels, behaviours and definition in three European countries. Journal of Psychologists and Counsellors in Schools, 20, 129-142. doi: 10.1375/ajgc.20.2.129.

Olweus, D. (1993). Bully/victim problems among schoolchildren: Long-term consequences and an effective intervention program. In S. Hodgins (Ed.) Mental disorder and crime (pp. 317-349). Thousand Oaks, CA: Sage.

Ortega-Ruiz, R., Elipe, P., Mora-Merchán, J. A., Genta, M. L., Brighi, A., Guarini, A., Smith, P. K., Thompson, F., \& Tippett, N. (2012). The emotional impact of bullying and cyberbullying on victims: A European cross-national study. Aggressive Behavior, 38, 342-356. doi: 10.1002/ab.21440.

Österman, K. (2008). The Mini-Direct and Indirect Aggression Scales. Vasa, Finland: Department of Developmental Psychology, Åbo Akademi University.

Patchin, J. W., \& Hinduja, S. (2006). Bullies move beyond the schoolyard: A preliminary look at cyberbullying. Youth Violence and Juvenile Justice, 4, 148-169. doi: 10.1177/15412040 06286288.

Raskauskas, J., \& Stoltz, A. D. (2007). Involvement in traditional and electronic bullying among adolescents. Developmental Psychology, 43, 564. doi: 10.1037/0012-1649.43.3.564.

Slee, P. T., \& Mohyla, J. (2014). The PEACE Pack: A computerized online assessment of school bullying. Journal of Educational Computing Research, 50, 431-447. https://doi.org/10.2190/EC.50.3.g

Slonje, R., Smith, P. K., \& Frisén, A. (2013). The nature of cyberbullying, and strategies for prevention. Computers in Human Behavior, 29, 26-32. doi: 10.1016/j.chb. 2012.05.024.

Slonje, R., \& Smith, P. K. (2008). Cyberbullying: Another main type of bullying? Scandinavian Journal of Psychology, 49, 147-154. doi:10.1111/j.1467-9450.2007.00611. x.

Smith, P. K., Görzig, A., \& Robinson, S. (2018). Issues of cross-cultural variations in cyber-bullying across Europe and beyond. Media@LSE Working Paper Series, WP 49.

Smith, P. K., Mahdavi, J., Carvalho, M., Fisher, S., Russell, S., \& Tippett, N. (2008). Cyberbullying: Its nature and impact in secondary school pupils. Journal of Child Psychology and Psychiatry, 49, 376-385. doi: 10.1111/j.1469-7610. 2007.01846.x.

Staksrud, E., Ólafsson, K., \& Livingstone, S. (2013). Does the use of social networking sites increase children's risk of harm? Computers in Human Behavior, 29, 40-50. doi: 10.1016/j.chb. 2012.05.026.

Thomas, H. J., Connor, J. P., \& Scott, J. G. (2014). Integrating school bullying and cyberbullying: Challenges of definition and measurement in adolescents-a Review. Educational Psychology Review, 27, 135-152. doi:10.1007/s10648-014-9261-7.

Tippett, N., \& Kwak, K. (2012). Cyberbullying in South Korea. In L. Qi, D. Cross, \& P. K. Smith (Eds.) Cyberbullying in the global playground: Research from international perspectives (pp. 202-219). Chichester, UK: WileyBlackwell.

Tokunaga, R. S. (2010). Following you home from school: A critical review and synthesis of research on cyberbullying 
victimization. Computers in Human Behavior, 26, 277- 287. doi:/10.1016/j.chb.2009.11.014.

Topcu, Ç., \& Erdur-Baker, Ö. (2010). The revised cyber bullying inventory (RCBI): Validity and reliability studies. Procedia-Social and Behavioral Sciences, 5, 660-664. doi: 10.1016/j.sbspro.2010.07.161

Tsitsika, A., Janikian, M., Wójcik, S., Makaruk, K., Tzavela, E., Tzavara, C., Greydanus, D., Merrick, J., \& Richardson, C. (2015). Cyberbullying victimization prevalence and associations with internalizing and externalizing problems among adolescents in six European countries. Computers in Human Behavior, 51, 17. doi: 10.1016/j.chb. 2015.04.048.

Tsitsika, A., Janikian, M., Tzavela, E., Schoenmakers, T. M., Ólafsson, K., Halapi, E., Tzavara, C., Wójcik, S., Makaruk, K., Critselis, E., Müller, K. W., Dreier, M., Holtz, S., Wölfling, K., Iordache, A., Oliaga, A., Chele, G., Macarie G., \& Richardson, C. (2013). Internet use and internet addictive behaviour among European adolescents: A cross-sectional study (EU NET ADB Project). Athens, Greece : National and Kapodistrian University of Athens.

Tsitsika, A., Tzavela, E., Mavromati, F., \& EU NET ADB Consortium. (2012). Research on internet addictive behaviours among European adolescents (EU NET ADB Project). Athens, Greece: National and Kapodistrian University of Athens.

Tsitsika, A., Critselis, E., Kormas, G., Filippopoulou, A., Tounissidou, D., Freskou, A., Spiliopoulou, T., Louizou, A., Konstantoulaki, E., \& Kafetzis, D. (2009). Internet use and misuse: A multivariate regression analysis of the predictive factors of internet use among Greek adolescents. European Journal of Pediatrics, 168, 655-665. doi: 10.1007/s00431-008-0811-1

Van den Berg, Y. H. M., \& Gommans, R. (2017). Computer-based methods for collecting peer nomination data: Utility, practice, and empirical support. New Directions for Child and Adolescent Development, 157, 61-73. doi: 10.1002/cad.20207.

Vieno, A., Gini, G., \& Santinello, M. (2011). Different forms of bullying and their association to smoking and drinking behavior in Italian adolescents. Journal of School Health, 81, 393-399. https://doi.org/10.1111/j.17461561.2011.00607.x.

Wachs, S., Jiskrova, G. K., Vazsonyi, A. T., Wolf, K. D., \& Junger, M. (2016). A cross-national study of direct and indirect effects of cyberbullying on cybergrooming victimization via self-esteem. Psicologia Educativa, 22, 61-70. doi:10.1016/j. pse. 2016.01.002.

Wachs, S., Wolf, K. D., \&. Pan C. C. (2012). Cybergrooming: Risk factors, coping strategies and associations with cyberbullying. Psicothema, 24, 628-633.

Willard, N. E. (2007). Cyberbullying and cyberthreats: Responding to the challenge of online social aggression, threats, and distress. Champaign, IL: Research Press.

Wright, M. F., Aoyama, I., Kamble, S. V., Li, Z., Soudi, S., Lei, L., \& Shu, C. (2015). Peer attachment and cyberaggression involvement among Chinese, Indian, and Japanese adolescents. Societies, 5, 339-353. doi:10.3390/soc5020339.

Ybarra, M. L., Diener-West, M., \& Leaf, P. J. (2007). Examining the overlap in Internet harassment and school bullying: Implications for school intervention. Journal of Adolescent Health, 41, 42-50. doi: 10.1016/j.jadohealth.2007.09.004.

Ybarra, M. L., \& Mitchell, K. J. (2004). Online aggressor/targets, aggressors, and targets: A comparison of associated youth characteristics. Journal of Child Psychology and Psychiatry, 45, 1308-1316. doi:10.1111/j.14697610.2004.00328.x.

Yudes-Gómez, C., Baridon-Chauvie, D., \& González-Cabrera, J. M. (2018). Cyberbullying and problematic Internet use in Colombia, Uruguay and Spain: Cross-cultural study. Comunicar, 56, 1-12.

Zych, I., Ortega-Ruiz, R., \& Del Rey, R. (2015). Systematic review of theoretical studies on bullying and cyberbullying: Facts, knowledge, prevention, and intervention. Aggression and Violent Behavior, $23,1-21$. doi: 10.1016/j.avb.201 5.10.001. 